\title{
Q fever outbreak among travelers to Germany associated with live cell therapy — United States and Canada, 2014: a co-publication ${ }^{\dagger}$
}

\author{
Robyn $\mathrm{MP}^{1,2^{*}}$, Newman $\mathrm{AP}^{2}$, Amato $\mathrm{M}^{3}$, Walawander $\mathrm{M}^{3}$, Kothe $\mathrm{C}^{4}$, Nerone $\mathrm{JD}^{4}$, Pomerantz $\mathrm{C}^{4}$, \\ Behravesh $\mathrm{CB}^{5}$, Biggs $\mathrm{HM}^{1,5}$, Dahlgren $\mathrm{FS}^{5}$, Pieracci $\mathrm{EG}^{1,5}$, Whitfield $\mathrm{Y}^{6}$, Sider $\mathrm{D}^{6}$, Ozaldin $\mathrm{O}^{7}$; \\ Berger $\mathrm{L}^{7}$; Buck $\mathrm{PA}^{8}$, Downing $\mathrm{M}^{9,10}$, Blog $\mathrm{D}^{2}$ \\ ${ }^{1}$ Epidemic Intelligence Service, Centers for Disease Control and Prevention, Atlanta, GA \\ ${ }^{2}$ New York State Department of Health, Albany, NY \\ ${ }^{3}$ Erie County Department of Health, Buffalo, NY \\ ${ }^{4}$ Ulster County Department of Health and Mental Health, Ellenville, NY \\ ${ }^{5}$ National Center for Emerging and Zoonotic Infectious Diseases, Centers for Disease Control and Prevention, Atlanta, \\ GA; \\ ${ }^{6}$ Public Health Ontario, Toronto, ON \\ ${ }^{7}$ Toronto Public Health, Toronto, ON \\ ${ }^{8}$ Centre for Food-borne, Environmental and Zoonotic Infectious Diseases, Public Health Agency of Canada, Ottawa, ON \\ ${ }^{9}$ Saint Joseph's Health Centre, Toronto, ON \\ ${ }^{10}$ Department of Medicine, University of Toronto, Toronto, ON
}

${ }^{\dagger}$ This paper is identical in content to the primary article published in the Morbidity and Mortality Weekly Report (MMWR) and released electronically on September 30, 2015 having met the guidelines for simultaneous publication as set forth by the International Committee of Medical Journal Editors (www.icmje.org).

*Correspondence: $\underline{\text { mrobyn@cdc.gov }}$

\section{Summary}

What is already known on this topic?

$\mathrm{Q}$ fever is a zoonotic disease caused by Coxiella burnetii and is usually transmitted through inhalation of air contaminated with animal excreta. The disease is considered to be underdiagnosed because symptoms are nonspecific and can vary from patient to patient, making diagnosis difficult.

\section{What is added by this report?}

During September-October 2014, the New York State Department of Health identified Q fever in five patients with exposure to a treatment known as live cell therapy, an alternative medicine practice involving injections of fetal sheep cells, which is a type of xenotransplantation. Investigation revealed that a group of U.S. residents traveled to Germany twice a year to receive this treatment.

\section{What are the implications for public health practice?}

Clinicians should consider zoonotic diseases, such as $\mathrm{Q}$ fever, in patients whose history includes receipt of a treatment known as live cell therapy. International travel for xenotransplantation procedures can facilitate transmission of zoonotic disease.

\section{Introduction}

During September-November 2014, the New York State Department of Health (NYSDOH) was notified of five New York state residents who had tested seropositive for Coxiella burnetii, the causative agent of $\mathrm{Q}$ fever. All five patients had symptoms compatible with $\mathrm{Q}$ fever (e.g., fever, fatigue, chills, and headache) and a history of travel to Germany to receive a medical treatment called "live cell therapy" (sometimes called "fresh cell therapy") in May 2014. Live cell therapy is the practice of injecting processed cells from organs or fetuses of nonhuman animals (e.g., sheep) into human recipients (1). It is advertised to treat a variety of health conditions. This practice is unavailable in the United States; however, persons can travel to foreign 
locations to receive injections. Local health departments interviewed the patients, and NYSDOH notified CDC and posted a report on CDC's Epidemic Information Exchange to solicit additional cases. Clinical and exposure information for each patient was reported to the Robert Koch Institute in Germany, which forwarded the information to local health authorities. A Canada resident who also received live cell therapy in May 2014 was diagnosed with Q fever in July 2014. Clinicians should be aware of health risks, such as $\mathrm{Q}$ fever and other zoonotic diseases, among patients with a history of receiving treatment with live cell therapy products.

The five New York patients had traveled in a group of 10-15 persons to the state of Rhineland-Palatinate in Germany to receive intramuscular injections of fetal sheep cells from a German physician on May 30, 2014. A Canada resident, who received intramuscular injections of fetal sheep cells from the same German physician on May 28, 2014, sought medical care in June 2014 for fever, pain, and erythema at the site of the injection. She received a diagnosis of Q fever in July 2014, and public health authorities were notified. Under International Health Regulations, the Public Health Agency of Canada notified German authorities in September 2014. At the time of notification, the ministry of health of the federal state of Rhineland-Palatinate was investigating an outbreak of human $\mathrm{Q}$ fever associated with inhalation exposure to a sheep flock that was used for production of fetal sheep cell injections by the German physician.

In September, the German physician notified patients treated during January-July 2014 of their potential $\mathrm{Q}$ fever exposure. This prompted $\mathrm{Q}$ fever testing of the five patients in New York, three of whom had already sought medical care for symptoms. The other two patients had experienced symptoms but had not sought medical care until notification of their potential $\mathrm{Q}$ fever exposure. The test results, with positive $\mathrm{Q}$ fever titers, were reported to NYSDOH and prompted investigation by local health departments. No additional U.S. or Canada residents with positive $\mathrm{Q}$ fever titers and history of intramuscular injections of fetal sheep cells in Germany have been identified. The identities and nationalities of the other persons in the travel group are unknown to U.S. and Canadian public health authorities. It is not known whether the other persons did not get tested for $\mathrm{Q}$ fever, tested negative, or did not report an exposure to fetal sheep cell injections.

An outbreak-associated case of $\mathrm{Q}$ fever was defined as an illness consisting of clinical signs and symptoms compatible with $Q$ fever, and a single IgG titer $\geq 1: 128$ to $C$. burnetii phase II antigen by immunofluorescence assay in a person who received live cell therapy in Germany during May 2014 (2). Among the six identified cases, the median patient age was 62 years (range $=59-83$ years). Four of the six patients were female. None of the patients reported other potential exposures to $\mathrm{Q}$ fever, with the exception of one patient who reported contact with sheep horn or bone. Three patients reported preexisting medical conditions: one patient with atrial fibrillation and kidney stones, one patient with Parkinson disease and osteoarthritis, and one patient with multiple sclerosis.

Signs and symptoms of $\mathrm{Q}$ fever began within approximately 1 week of receipt of the intramuscular injections of fetal sheep cells. The majority of symptoms were reported as lasting approximately 10-90 days; however, 9-10 months after exposure, three patients continued to report symptoms of fatigue, chills, sweats, and difficulty sleeping (Table). One patient had initially reported no symptoms during an interview with the local health department after his positive titers were reported in November 2014; however, in February 2015, he informed his physician that symptoms had been occurring since the injections in May.

The patients were tested for Q fever phase I and phase II antibodies at 2-6 months after exposure, using indirect immunofluorescence assay. C. burnetii undergoes antigenic phase variation, between a virulent phase I form and an avirulent phase II form. During acute infection, phase II antibodies appear first and are higher than phase I antibodies. All patients' phase I IgG titers were elevated (1:512-1:2,048), but were lower than phase II IgG titers (1:4,096-1:65,536), suggesting acute disease. Phase I IgM titers were elevated in four patients $(1: 128-1: 8,192)$ and phase II IgM titers were elevated in all patients $(1: 64-1: 32,768)$. All patients were treated with doxycycline after receiving a diagnosis of $Q$ fever.

All six patients were initially interviewed by their local health departments; only two of the five New York patients agreed to a follow-up interview by NYSDOH. The two patients reported that a group had traveled to Germany for injections twice each year for the past 5 years. They chose to receive injections of fetal sheep cells to improve their general health and vitality, and had not previously experienced signs or symptoms of 
illness after injections. They reported that they were not informed of a risk for $\mathrm{Q}$ fever infection before injection.

\begin{tabular}{|c|c|c|c|c|c|c|}
\hline Sign/Symptom & Patient 1 & Patient 2* & Patient 3 & Patient 4 & Patient 5 & Patient 6 \\
\hline Fever & $\mathrm{X}$ & & $\mathrm{X}$ & $\mathrm{X}$ & $\mathrm{X}$ & $\mathrm{X}$ \\
\hline Sweats & $\mathrm{x}$ & & $\mathrm{X}$ & $x$ & $x$ & \\
\hline Fatigue & $\mathrm{x}$ & $\mathrm{X}$ & & $\mathrm{X}$ & $\mathrm{X}$ & $\mathrm{X}$ \\
\hline Headache & $\mathrm{X}$ & & $\mathrm{X}$ & & $\mathrm{X}$ & \\
\hline Chills & $\mathrm{X}$ & $\mathrm{X}$ & $\mathrm{X}$ & & & \\
\hline Malaise & & & $\mathrm{X}$ & $\mathrm{X}$ & $\mathrm{x}$ & \\
\hline Cellulitis & & & $x$ & & $x$ & $x$ \\
\hline Confusion & $\mathrm{X}$ & & & & & \\
\hline Retrobulbar pain & $\mathrm{X}$ & & & & & \\
\hline Injection site abscess & & & $\mathrm{X}$ & & & \\
\hline Cough & & & $\mathrm{X}$ & & & \\
\hline Dizziness & & & $\mathrm{X}$ & & & \\
\hline Shortness of breath & & & $\mathrm{X}$ & & & $\mathrm{x}$ \\
\hline Sore throat & & & $x$ & & & \\
\hline Dry mouth & & & $x$ & & & \\
\hline Diarrhea & & & $x$ & & & \\
\hline Difficulty sleeping & & & & $x$ & & \\
\hline Joint pain & & & & & $x$ & \\
\hline Myalgia & & & & & $\mathrm{X}$ & \\
\hline Duration & $10-30$ days & $\begin{array}{c}9 \text { months } \\
\text { (fatigue and } \\
\text { chills were } \\
\text { ongoing as of } \\
\text { February 2015) }\end{array}$ & $2-3$ months & $\begin{array}{l}\text { 14-30 days } \\
\text { (fatigue and } \\
\text { difficulty } \\
\text { sleeping were } \\
\text { ongoing as of } \\
\text { February 2015) }\end{array}$ & $\begin{array}{l}30 \text { days (fatigue } \\
\text { and sweats were } \\
\text { ongoing as of } \\
\text { February 2015) }\end{array}$ & $\begin{array}{l}10 \text { days (fatigue } \\
\text { continued for } \\
\text { several months) }\end{array}$ \\
\hline
\end{tabular}

*Patient 2 initially reported no symptoms.

\section{Discussion}

The treatment known as live cell therapy was developed in Switzerland during the 1930s by Paul Niehans. Practitioners have used organs, glands, and fetuses of multiple species, including sheep, cows, and sharks. * (1).

No published clinical evidence supporting therapeutic claims of the treatment known as live cell therapy is available. It is advertised as having anti-aging effects and as a treatment for multiple conditions and diseases (e.g., erectile dysfunction, depression, and joint, neurologic, heart, kidney, lung, endocrine, and liver disease). ${ }^{\dagger}$ Serious adverse events have been reported, including anaphylaxis, vasculitis, encephalitis, polyradiculitis, clostridial infections, paresis, and death (3-5).

The treatment known as live cell therapy is a type of xenotransplantation when it involves administration of live cells from a nonhuman animal source into a human recipient (6). Xenotransplantation carries a public health risk for transmission of known and unknown infectious agents from the donor organism to the human recipient and possible recombination or reassortment to form new pathogens (6). There is a theoretic potential for dissemination of disease from the original recipient to others. For this reason, discussions on safety requirements for xenotransplantation by international and domestic public health agencies continue to occur (7).

Regulation of xenotransplantation varies among countries. In the United States, the Food and Drug Administration (FDA) regulates xenotransplantation products as Biologic Drugs under section 351 of the Public Health Service Act ${ }^{\S}$ and the Federal Food, Drug, and Cosmetic Act. " FDA approval of a Biologics License Application (BLA) is required to introduce, or deliver for introduction, a biologic product into interstate commerce. FDA has not approved a BLA for a xenotransplantation product known as live cell 
therapy. If a xenotransplantation product is proposed for use in a clinical investigation in the United States, an Investigational New Drug Application would be required. In Canada, xenotransplantation cell therapy products are regulated as drugs under the Food and Drugs Act ${ }^{* *}$ and the Food and Drug Regulations. ${ }^{\dagger}$ Authorities in Canada have not authorized for sale any xenotransplantation products, nor have any clinical trials that involve xenotransplantation been authorized. In Germany, xenotransplantation products are regulated under the Medicinal Products Act; however, an attempt to ban fresh cell therapy in 1997 was later determined to be null and void because the federal law does not cover drugs manufactured by doctors only for use in their own patients (8). According to an assessment supported by the World Health Organization and its partners, during January 1994-September 2009, xenotransplantation procedures were identified in 12 different countries, of which nine had no clear national regulations on xenotransplantation (9).

This outbreak highlights one of the public health issues associated with xenotourism, the travel outside a country of residence for the purpose of participating in xenotransplantation programs. FDA recommends that xenotransplantation product recipients enrolled in research studies remain under lifelong surveillance with periodic clinical and laboratory monitoring and that both they and their intimate contacts refrain from blood and tissue donation (6). However, other than self-reporting, no method to identify returned xenotourists is available. Clinicians should be aware of xenotourism and consider the potential for zoonotic disease in a patient with a history of xenotransplantation.

\section{Acknowledgments}

Stephen Moore, Ryan Walton, Bryna Warshawsky, MD, Public Health Ontario. Samir N Patel, PhD, Public Health Ontario and University of Toronto. Maja George, PhD, Robert Koch Institute and European Centre for Disease Prevention and Control. Ann Sullivan-Frohm, Christina Hidalgo, MPH, Philip Kurpiel, PhD, New York State Department of Health. Canada IHR National Focal Point Office, Public Health Agency of Canada.

\section{References}

(1) U.S. Congress, Office of Technology Assessment, Unconventional Cancer Treatments, OTA-H-405. Washington, DC: U.S. Government Printing Office; September 1990.

(2) Centers for Disease Control and Prevention. Notes from the field: Q fever outbreak associated with goat farmsWashington and Montana, 2011. Morb Mortal Wkly Rep 2011;60;1393.

(3) Bohl J, Goebel HH, Potsch L, Esinger W, Walther G, Mattern R, et al. Complications following cell therapy. Zeitschrift fur Rechtsmedizin 1989;103:1-20.

(4) Goebel HH, Walther G, Meuth M. Fresh cell therapy followed by fatal coma. J Neurol 1986;233:242-7.

(5) The Lancet. Cell therapy suspended. Lancet. 1987; 330(8557):503.

(6) Guidance for Industry: Source animal, product, preclinical, and clinical issues concerning the use of xenotransplantation products in humans. U.S. Department of Health and Human Services, Food and Drug Administration, Center for Biologics and Research; 2003 April. http://www.fda.gov/BiologicsBloodVaccines/GuidanceComplianceRegulatoryInformation/Guidances/Xenotranspla ntation/ucm074354.htm.

(7) World Health Organization. Second WHO Global Consultation on Regulatory Requirements for Xenotransplantation Clinical Trials. Geneva, Switzerland; October 17-19, 2011. http://www.who.int/transplantation/xeno/report2nd_global_consultation_xtx.pdf?ua=1.

(8) Federal Constitutional Court. Ban on fresh cell production is void. Bund has no regulatory powers. Press release No. 18/2000; February 16, 2000 [German]. http://www.bundesverfassungsgericht.de/SharedDocs/Pressemitteilungen/DE/2000/bvg00-018.html.

(9) Sgroi A, Bühler LH, Morel P, Sykes M, Noel L. International human xenotransplantation inventory. Transplantation 2010;90:597-603.

* Additional information available at http://www.extendlife.com/livecell.php.

${ }^{\dagger}$ Additional information available at http://www.janson-mueller.de/index.php?id=22\&L=2.

$\S 42$ U.S.C. 262.

" 21 U.S.C. 321 et seq.

** R.S.C., 1985, c. F-27.

${ }^{\dagger \dagger}$ C.R.C., C. 870. 